\title{
Pulmonary alveolar microlithiasis with involvement of the sympathetic nervous system and gonads
}

\author{
T. COETZEE \\ Nababeep, Cape Province, South Africa
}

\begin{abstract}
Pulmonary alveolar microlithiasis is a relatively rare disease, of obscure aetiology, manifested by the presence of intra-alveolar laminated concretions distributed diffusely throughout the lungs. In all the recorded cases disease has been limited to the lungs and similar lesions have not been observed in other organs or tissues.

The findings in a patient in whom lesions identical to those in the lungs were confirmed in the lumbar sympathetic chain and suspected to be present in the testes are recorded.
\end{abstract}

\section{CASE REPORT}

The patient, an African man aged 24 years from the Griqualand East area of South Africa, came under medical care in October 1963 when he presented with an attack of acute abdominal pain. No diagnosis was made. He had a similar attack three months later. Examination was largely negative. Radiographs of the pelvis showed scattered lines of calcification, not characteristic of that occurring in bilharzial involvement of the bladder. Laparotomy revealed no gross abnormalities. Because the possibility of a recurring pancreatitis could not be excluded, a sphincterotomy was performed.

He was seen by the author four months later, during an attack of abdominal pain associated with diarrhoea, vomiting, and urinary difficulty. He responded slowly to conservative treatment and it was decided to undertake further special examinations in an attempt to establish a diagnosis.

Special interrogation revealed that the patient had three brothers and three sisters. One sister had died at 23 years of age of a lung disease, but no details were available. Two brothers were available for medical examination: they were both in good health and chest radiographs were normal. There was no history of taking snuff or chewing tobacco. He smoked and drank beer in moderation. There was no opportunity for close contact with bats.

The patient appeared thin but was otherwise in good physical condition. There were no significant findings on general examination apart from slight hyperextensibility of the finger joints. Clinical examination of the respiratory, cardiovascular, and nervous systems revealed no abnormalities. The abdomen showed normal findings on examination.

The chest radiograph showed miliary opacities scattered throughout both lungs (Fig. 1). Repeated sputum examinations were negative for tuberculosis and showed no malignant cells. An intravenous pyelo- gram showed normal renal excretion and anatomy and a normal cystogram with good bladder evacuation. The urine was normal on chemical and microscopic examination. The linear opacities previously noted were seen in the pelvis, and a linear opacity could also be distinguished in the paravertebral position on both sides, presenting a localized enlargement in relation to such intervertebral foramen in the lumbar and sacral regions (Fig. 2). Although the nature of these shadows could not then be determined it was noted that their position and configuration corresponded with that of the lumbar sympathetic chain. Examination of the calcium and phosphorus metabolism showed no abnormality. A complete skeletal survey showed no abnormalities in bone texture. On reviewing the radiographs of the pelvis it was noted that the testicular shadows were dense and showed diffuse miliary mottling identical with the pattern of the lung fields (Fig. 3). Cystoscopic examination showed normal features and a mucosal biopsy showed no evidence of bilharziasis. Several specimens of faeces failed to show any ova, parasites, or occult blood.

A barium enema examination and sigmoidoscopy showed normal appearances. The patient's blood group was $\mathrm{A}, \mathrm{Rh}$ negative. A study of the peripheral blood showed normal findings apart from a lymphocytosis of $46 \%$. The Wassermann reaction of the blood and cerebrospinal fluid was negative.

Further laparotomy was performed in September 1964. The abdominal viscera were normal in every respect. The lumbar sympathetic chains were exposed. The chain was grossly thickened (with an average diameter of $4 \mathrm{~mm}$.) and indurated. The ganglia were enlarged to a transverse diameter exceeding $8 \mathrm{~mm}$. Nodular thickening of the autonomic nerves was palpable in the presacral area. The right lumbar sympathetic chain, with the second, third, and fourth ganglia, was removed. A biopsy was taken from the right lung. The lung appeared normal on naked-eye 
FIG. 1. Chest radiograph showing diffuse miliary mottling.

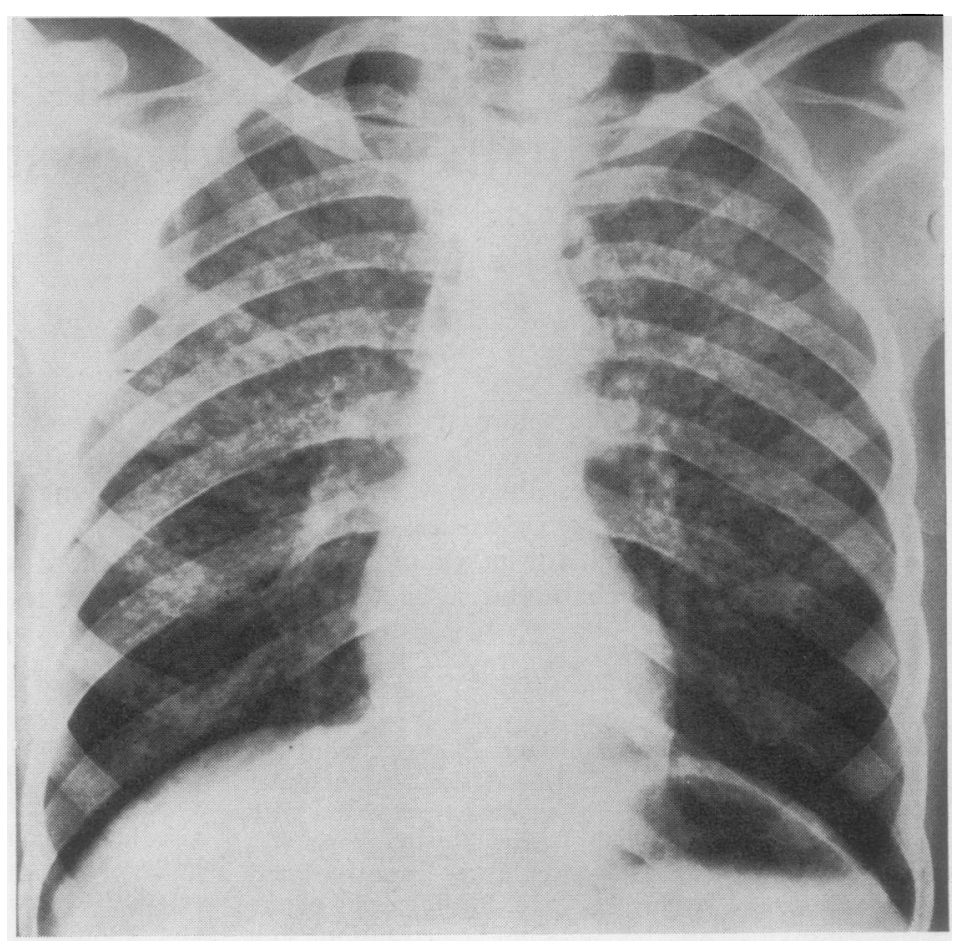

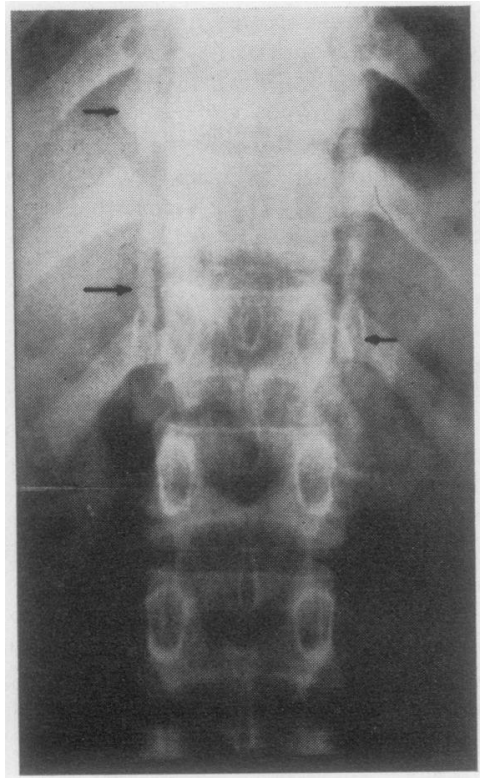

FIG. 2. Linear opacities in paravertebral position with thickening at intervertebral level.

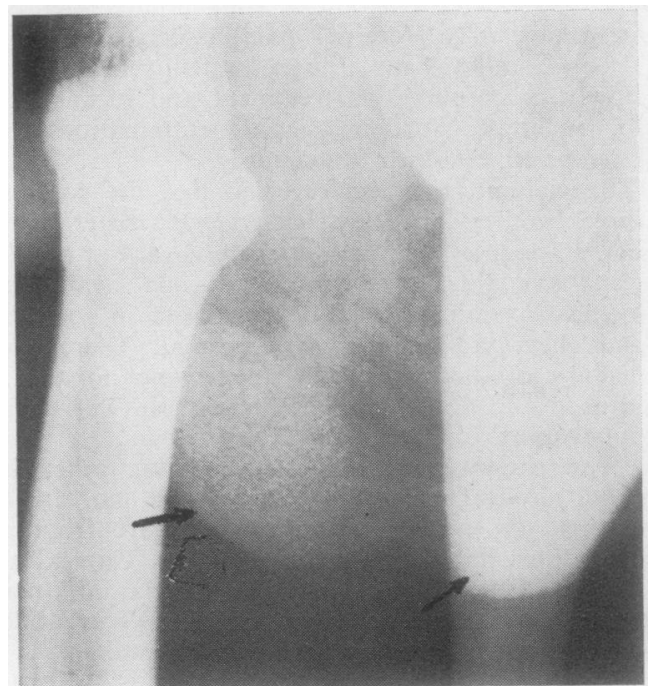

FIG. 3. Diffuse miliary mottling outlining both testes. 


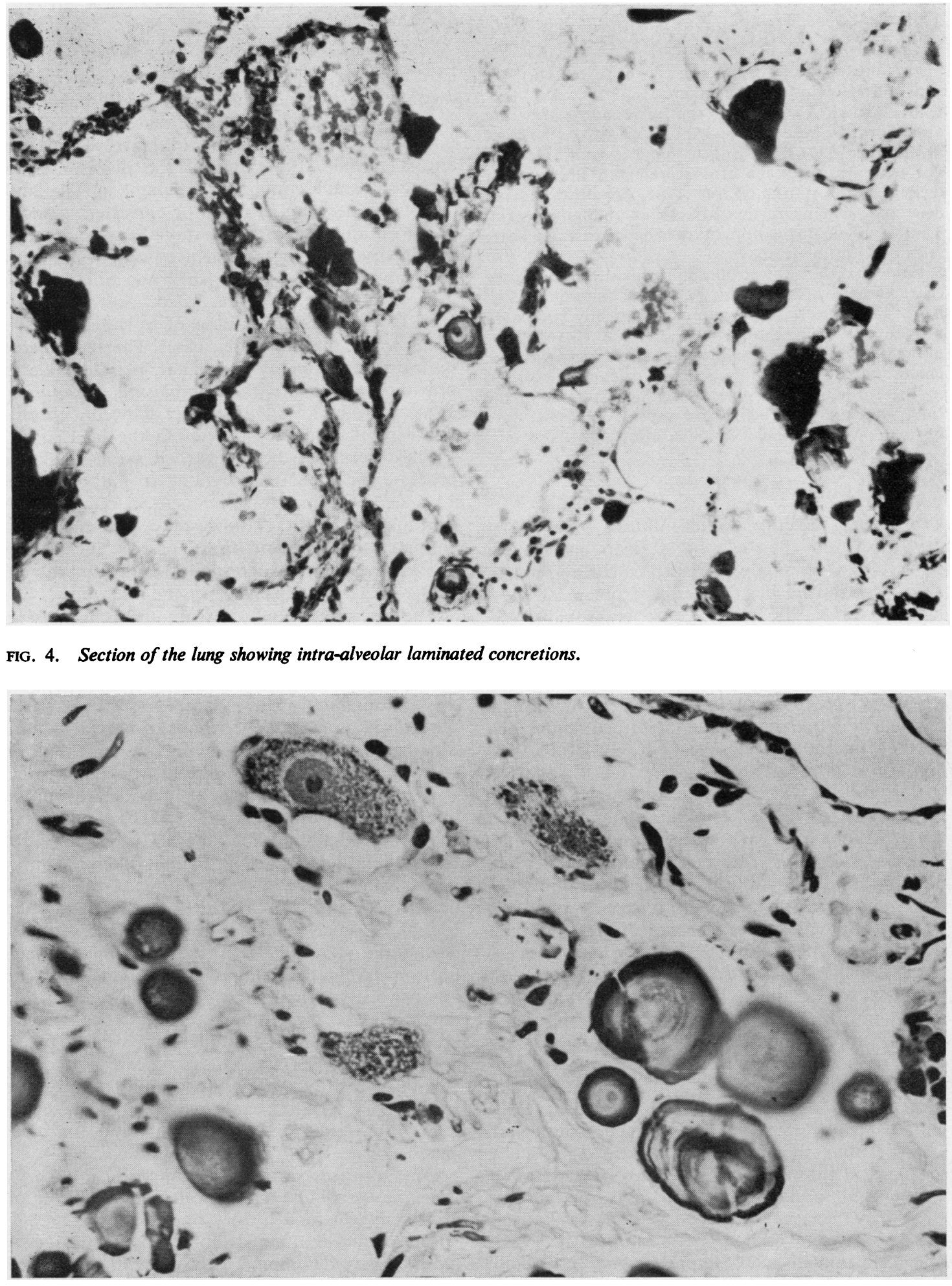

FIG. 5. Section of sympathetic ganglion (high power) showing laminated concretions. Sympathetic ganglion cells are seen. 
inspection but was distinctly gritty on palpation. Skin and muscle biopsies were taken.

The patient made an uneventful recovery after the operation and when he was discharged from hospital in October 1964 had gained some weight. He was not seen again but his brother reported that he had died at home during March 1965, his death having been preceded by further attacks of abdominal pain. There was no indication of cardiac disease or heart failure prior to death.

Lung biopsy showed the histological appearance characteristic of pulmonary alveolar microlithiasis: many alveoli were filled with concentrically laminated microliths within the alveolar lumina. No inflammatory reaction was present (Fig. 4). The sympathetic chain and ganglia showed a heavy calcium deposition in the form of calcospherites similar to those in the lung (Fig. 5). The skin and muscle biopsies were normal on histological examination.

\section{DISCUSSION}

Pulmonary alveolar microlithiasis was first described more than a hundred years ago (Friedreich, 1856a, b, c). It was first so called by Puhr in 1933. Cases have been reported from most parts of the world. The present case is probably the first one from southern Africa. The disease affects males and females in roughly equal numbers. The ages of reported cases have ranged between 6 and 72 years. More recently, several asymptomatic cases in children have been described, often discovered on routine chest radiographs of the siblings of known cases.

The disease is a chronic one and probably always has a long asymptomatic phase. The condition is known to have been present for 25 years (Manz, 1954). Most cases are asymptomatic when discovered, usually during medical examination for employment or military service.

The aetiology and the nature of the condition have been much discussed. Many examples of familial incidence have been reported. Amongst the 26 cases described by Sosman, Dodd, Jones, and Pillmore (1957) there were five instances in which several members of one family were affected. This has suggested the possibility of heredity, environment, diet or contagion as aetiological factors. No consistent bacterial or other (e.g., fungal) infection has been demonstrated. The calcium metabolism has been specifically screened in many cases. Mikhailov (1954) found an elevated serum calcium in three cases. Renal stones have been reported in several cases (Badger, Gottlieb, and Gaensler, 1955 ; Sosman et al., 1957 ; Portnoy, Amadeo, and Henningar, 1964). O'Neill, Cohn, and Pellegrino (1967) did a particularly careful study of the calcium metabolism in three members of a family and found no derangement. No instance of parathyroid disease has been reported in a patient with microlithiasis. Chinachoti and Tangchai (1957) related the disease to the taking of snuff containing calcium, in Thailand. There has been no constant or consistent association with any type of occupational exposure, antecedent disease or involvement of other organs.

Involvement of other organs by a similar disease process has not been recorded. Sosman et al. (1957) described the finding of calcified nodules in the spleen in one of their cases. They considered these to be probably incidental, possibly due to previous infection with Histoplasma capsulatum. Two of Mikhailov's (1954) cases showed a chronic nodular inflammatory process in the liver.

The disease has been regarded as an exudative process, the exudate providing a suitable intraalvcolar mcdium for subsequent calcification. A continuing process is suggested; new microliths continue to form and those present increase in size as the disease progresses. There is no reaction in the lung to the presence of the microliths.

The disease is usually asymptomatic, usually an incidental radiographic finding. Symptoms, when they arise, are those of pulmunary insufficiency with, finally, symptoms of heart failure due to cor pulmonale. There are no characteristic physical findings and the results of special laboratory examinations are essentially non-contributory.

The diagnosis is suggested by the radiological appearance of the lung fields. There are diffuse, fine, sand-like or granular opacities spread uniformly throughout both lungs. The granules are usually less than $1 \mathrm{~mm}$. in diameter. They appear denser at the lung bases because of the greater depth of lung tissue. The density of the nodules is that of calcium and it is this calcific density, cven more strikingly demonstrated under magnification of an over-exposed film, in the total absence of clinical signs and symptoms, that differentiates microlithiasis from other miliary conditions which may simulate it. Miliary tuberculosis, miliary metastases, sarcoidosis, pulmonary haemosiderosis, pulmonary eosinophilia and other rarer miliary diseases can usually be recognized by their appearance and distribution and the associated physical and laboratory findings.

Dust diseases, especially stannosis and berylliosis, have a different appearance and distribution and there will be a history of exposure.

The diagnosis of microlithiasis is confirmed by lung biopsy. The lung feels distinctly gritty on palpation. The microscopical appearance of 
laminated intra-alveolar concretions is typical of the disease.

No method of treatment has been shown to influence the course of the disease.

Two aspects of the case here reported deserve further mention. Firstly, no satisfactory explanation of the recurrent attacks of abdominal pain was found. Could pain arise from irritation of the sympathetic ganglion cells by the calcified deposits and be distributed along the sympathetic pathways? Such sympathetic overactivity may possibly explain the mild ileus and urinary difficulty observed during an attack.

Secondly, the discovery of lesions identical with those of pulmonary microlithiasis in the sympathetic nervous system and in the testes probably provides support for postulating a systemic or metabolic derangement as an aetiological factor. The peculiar localization of lesions in the nervous and reproductive systems must remain unexplained.

\section{REFERENCES}

Badger, T. L., Gottlieb, L., and Gaensler, E. A. (1955). Pulmonary alveolar microlithiasis, or calcinosis of the lungs. New Fingl. J. Med., 253, 709.

Chinachoti, N., and Tangchai, P. (1957). Pulmonary alveolar microlithiasis associated with the inhalation of snuff in Thailand. Dis. Chest, 32, 687.

Friedreich, N. (1856a). Corpora amylacea in den Lungen. Virchows Arch. path. Anat., 9, 613 .

(1856b). Weitere Mitteilungen über Corpora amylacea in den Lungen. Virchows Arch. path. Anat., 10, 201.

- (1956c). Zur Entwickelungsgeschichte der Corpora amylacea in den Lungen. Virchows Arch. path Anat., 10, 507.

Manz, A. (1954). Mikrolithiasis der Lungen mit Pilzbefall. Beitr. klin. Tuberk., 111, 598.

Mikhailov, V. (1954). Pulmolithiasis endoalveolaris et interstitialis diffusa. Klin. Med. (Mosk), 32, no. 3, p. 31. (In Russian.)

O'Neill, R. P., Cohn, J. F., and Pellegrino, E. D. (1967). Pulmonary alveolar microlithiasis-a family study. Ann. intern. Med..67, 957.

Portnoy, L. M., Amadeo, B., and Hennigar, G. R. (1964). Pulmonary alveolar microlithiasis; an unusual case (associated with milkalkali syndrome). Amer. J. clin. Path., 41, 194.

Puhr, L. (1933). Mikrolithiasis alveolaris pulmonum. Virchows Arch. path. Anat., 290, 156.

Sosman, M. C., Dodd, G. D., Jones, W. D., and Pillmore, G. U. (1957). The familial occurrence of pulmonary alveolar microlithiasis. Amer. J. Roentgenol., 77, 947.

A full bibliography is appended.

\section{ADDITIONAL BIBLIOGRAPHY}

Harbitz, F. (1918). Extensive calcification of the lungs as a distinct disease. Arch. intern. Med., 21, 139.

Schildknecht, O. (1932). Zur Pathogenese verkalkter Schichtungskugeln, sog. "Corpora amylacea" in der Lunge. Virchows Arch. path. Anat., 285, 466.

Mariani, B., Montanini, N., and Torelli, G. (1947). Microlitiasi polmondre endoalveolare diffusa. Ann. Ist. Forlalini, 10, 179.

Leicher, F. (1949). Utber eine generalisierte Lungenerkrankung mit Konkrementbildung (Mikrolithiasis alveolaris pulmonum). Zbl. allg. Path., 85, 49.

Bénard, H., Rambert, P., Péquignot, H., Tissier, and Galistin, P. (1950). Microlithiase alvéolaire diffuse. Bull. Soc. méd. Hôp., Paris, 66, 482.

Lindig, W. (1951). Ein klinisch-röntgenologischer Beitrag zum Krankheitsbild der " Mikrolithiasis alveolaris pulmonum". Fortschr. Röntgenstr., 75, 678.
Sharp, M. E., and Danino, E. A. (1953). An unusual form of pulmonary calcification: "microlithiasis alveolaris pulmonum". J. Path. Bact., 65, 389.

Petrányi, G., and Zsebök, Z. (1954). Mikrolithiasis alveolaris miliaris pulmonum. Radiol. clin. (Basel), 23, 202.

Takahashi, Y. A. (1954). A case report of microlithiasis alveolaris pulmonum. Nippon Rinsho, 12, 89.

Sato, K. (1955). Three cases of microlithiasis alveolaris pulmonum occurring in one family. Sci. Rep. Res. Inst. Tohoku Univ., Ser. C, 6, 391.

Klemm, F. W. (1955). Ein weiterer Beitrag zum Krankheitsbild der Mikrolithiasis alveolaris miliaris pulmonum. Fortschr. Röntgenstr., 83, 686.

Kent, G., Gilbert, E. S., and Meyer, H. H. (1955). Pulmonary microlithiasis: microlithiasis alveolaris pulmonum. Arch. Path., 60, 556.

Hirota, S. (1955). Microlithiasis alveolaris pulmonum. Nippon Rinsho, 14, 834

Gough, J. (1955). Correlation of radiological and pathological changes in some diseases of the lung. Lancet, 1,161 .

Meyer, H. H., Gilbert, E. S., and Kent, G. (1956). A clinical review of pulmonary microlithiasis. J. Amer. med. Ass., 161, 1153.

Biressi, P. C., and Casassa, P. M. (1956). La microlitiasi polmonare endoalveolare. Minerva med. (parte sci.), 47 (2), 930.

Gilsanz, V., Palacios, J. M., and Alonso Barrera, J. M. (1956). Microlitiasis alveolar. Rev. clin. esp., 61, 392.

Finkbiner, R. B., Decker, J. P., and Cooper, D. A. (1957). Pulmonary alveolar microlithiasis. Amer. Rev. Tuberc., 75, 122.

Maser, W. (1957). Microlithiasis alveolaris pulmonum von 14jähriger Dauer und Progredienz. Beitr. path. Anat., 118, 436.

Greenberg, M. J. (1957). Miliary shadows in the lungs due to microlithiasis alveolaris pulmonum. Thorax, 12, 171 .

Foote, E. L. (1957). Microlithiasis alveolaris pulmonum: a case report. J. Maine med. Ass., 48, 230.

Mikhailov, V., Prodanov, A., and Rashev, M. (1956). Problem of pulmolithiasis endo-alveolaris diffusa. Arkh. pat. 18, no. 8, p. 73. (In Russian.)

Gaudieri, A., and Magliaro, M. (1957). Sulla microlitiasi, polmonare endoalveolare diffusa. Rif. med., 71, 1017.

Semelaigne, G., Hurez, A., and Le Braz, A. (1958). Familial pulmonary micronodularity images, very probable diffuse alveolar microlithiasis. Arch. frang. Pédiat., 15, 670.

Laake, H. (1959). Calcification of the lungs. Acta tuberc. scand., 36, 249.

Hojman, D., Podio, R. B., and de Barreiro, O. C. (1958). Mikrolithiasis falveolaris pulmonum. Rev. Asoc. méd. argent., 72, 411

Thomson, W. B. (1959). Pulmonary alveolar microlithiasis. Thorax, $14,76$.

Abdel-Hakim, M., El-Mallah. S., Hashem, M., and Abdel-Halim, S. (1959). Pulmonary alveolar microlithiasis. Thorax, 14, 263.

Esguerra Gómez, G., Lichtemberger, E., Santamaría, A., Carvajal, L., Jiménez-Peñuela, B., Saaibí, E., Rey Barrera, A., Ordùz, E., and Correa-Henao, A. (1959). Familial pulmonary alveolar microlithiasis: Four cases from Colombia, S.A. Radiology, 72, 550.

Morrow, C. S., and Staskiel, L. J. (1959). Pneumoliths in profusion in silicosis. Amer. Rev. Tuberc., 79, 512.

Freour, P., Laumonnier, P., Verger, P., Germouty, R., Cardinaud, R., and Cardinaud, J. P. (1959). Les microlithiases pulmonaires alveolaires. J. Méd. Bordeaux, 136, 459.

Waters, M. H. (1960). Microlithiasis alveolaris pulmonum. Tubercle (Lond.), 41, 276.

Sarkissian, S., and Shamsa, A. M. (1960). A case of pulmonary microlithiasis. Acta med. iran., 3, no. 12

Taxay, E. P., Montgomery, R. D., and Wildish, D. M. (1960). Studies of pulmonary alveolar microlithiasis and pulmonary alveolar proteinosis. Amer. J. clin. Path., 34, 532.

Soter, C., Berkmen, Y., Gür, H., Hadzidakis, A. A., and Gilmore, J. H. (1960). Ossifying pneumonitis and calcinosis: report of a case. Acta radiol. (Stock.), 54, 195.

Ata, A. A., and El-Rooby, A. (1961). Microlithiasis alveolaris pulmonum. J. Egypt. med. Ass., 44, 996.

El-Kateb, H. (1961). Microlithiasis alveolaris pulmonum. J. Egypt. med. Ass., 44, 1003.

Clark, R. B., and Johnson, F. C. (1961). Idiopathic pulmonary alveolar microlithiasis; A case report and brief review of the literature. Pediatrics, 28, 650.

Viswanathan, R. (1962). Pulmonary alveolar microlithiasis. Thorax, $17,251$.

Supramaniam, J. M. J. (1962). The first case of broncholithiasis in Singapore. Singapore med. J., 3, 94.

Tatti, V., and Riniker, P. (1962). Microlithiase alvéolaire pulmonaire diffuse et familiale. Helv. med. Acta, 29, 611 . 
Varma, B. N. (1963). Pulmonary alveolar microlithiasis in a child of 13 years. Brit. J. Dis. Chest, 57, 213.

Baar, H. S., and Ferguson, F. F. (1963). Microlithiasis alveolaris pulmonum; association with diffuse interstitial pulmonary fibrosis. Arch. Path., 76, 659.

Rotem, Y., Solomon, M., and Hertz-Frankenhuis, M. (1963). Pulmonary alveolar microlithiasis. Ann. paediat. (Basel), 201, 4.

Yang, S., and Lin, C. (1963). Pulmonary alveolaris microlithiasis: a report of two youngest cases in a family. Dis. Chest, 44, 163.

Lebacq, E., Lauweryns, J., and Billiet, L. (1964). Pulmonary alveolar microlithiasis; Case report with lung function studies. Brit. J. Dis. Chest, 58, 31 .

Röher, H. D., and Michel, H. (1965). Mikrolithiasis alveolaris pulmonum. Med. Welt (Stuttg.), 42, 2395.

Sanz Martín, F., Culebras, A., Antón, T., Oliva, H., and Romeo Orbegozo, J. M. (1965). Pulmonary alveolar microlithiasis: revision of literature in view of two new cases. Bull. Inst. med. Res. (Madr.), 18, 35 .

Bhattacharjee, B. K., Barua, R., and Duta, J. K. (1965). Pulmonary alveolar microlithiasis. Indian J. Chest Dis., 7,51 .

Tezok, F., Balci, K., Baris, I., and Kurt, C. (1965). Un cas de microlithiase alvéolaire pulmonaire diffuse. Rev. méd. Moy. Or., 22, 447.

Oka, S., Shiraishi, K., Ogata, K., Goto, Y., Yasuda, T., and Yanagihara, H. (1966). Pulmonary alveolar microlithiasis; report of 3 cases. Amer. Rev. resp. Dis., 93, 612.

Kamada, T. (1966). Pulmonary alveolar microlithiasis. Hiroshima J. med. Sci., 15, 95 .
Okuno, K., Chlhaya, M., Kumamoto, S. et al. (1966). Two familial cases of microlithiasis alveolaris pulmonum. Runsho Hosha 2, 44 .

Maritines, F. (1966). Intra-alveolar microlithiasis of the lung; diagnostic and differential diagnostic criteria in $\mathbf{2}$ familial cases. Rev. bras. Biol., 26, 1465.

Burguet, W., and Reginster, A. (1967). L'Hérédité de la microlithiase alvéolaire pulmonaire à propos d'une nouvelle observation familiale. Ann. Génét., 10, 75.

Banerjea, J. C., Mukerji, A., and Maiti, C. R. (1967). Chronic cor pulmonale due to pulmonary alveolar microlithiasis. Indian Heart J., 19, 47.

Rajagopalan, C. R., Krishna, K. V. S., Rao, M., and Babu, T. N. (1967). Pulmonary alveolar microlithiasis; report of a case. Indian J. Pediat., 34, 328.

Mariani, B., and Bassi, A. (1967). Attualità in tema di microlitiasi polmonare endoalveolare (malattia di Malpighi). Minerva med. (parte sci.), 58, 3761.

Hatano, S., Ueda, H., Murao, M., et al. (1967). Pulmonary alveolar microlithiasis. Naika, 19, 909 .

Mándi, L., Simay, A., Kelmen, J. T., Szabó, A., and Dayka, A. (1968). Microlithiasis alveolaris pulmonum. Orv. Hetil., 109, 1463. (In Hungarian.)

Sambasiva Rao, C. Madhusudhana Rao, Y. Bhaskara Reddy, D. and Sarada, D. (1968). Pulmonary alveolar microlithiasis. J. Indian med. Ass., 50, 427.

Fuleihan, F. J. D., Abboud, R. T., Balikian, J. P., and Nucho, C. K. N. (1969). Pulmonary alveolar microlithiasis; lung function in 5 cases. Thorax, $24,84$. 